\title{
Experimental Research on Shear Ductility of Regional Confined Concrete Beam
}

\author{
Qinggui Wu ${ }^{1}$ Xinming Cao ${ }^{1}$ Guyue Guo ${ }^{1}$ \\ ${ }^{1}$ College of Civil Engineering, Guizhou University , Guiyang 550025, China
}

\begin{abstract}
In efforts to study the shear ductility of regional confined concrete beam, 5 reinforced concrete beams were tested to examine its shear performance. These beams has the same shear span ratio, concrete strength, different ratios of tension reinforcement and shapes of stirrup. The purpose of the test is studying the effects of stirrup shape and tension reinforcement ratio on failure mode and shear ductility. The test shows that the regional confined part can be used as an independent part and the rest of the beam is good to work together so that the ductility of the beam is more one time higher than that of the normal confined concrete beam. The related laws of the effect of tension reinforcement ratio and stirrup shapes on beam's shear ductility were founded
\end{abstract}

\section{Introduction}

Reginal Confined Concrete (RCC) is a kind of confined concrete conception and was put forward by Cao xinming (2013). RCC has been developed into relative mature theory. It has been employed into many engineering practice and brought about great economical merits.

A measure of the ductility of a structure is the displacement ductility coefficient. It defined as the lateral deflection at the end of the post-elastic range divided by the lateral deflection when yield is first reached (park 1975). Ahmad Sh (1994) has defined the shear ductility coefficient by imitating the analysis method of normal section ductility .Yi Weijian (2009) has done the research on regularity of shear ductility of normal confined concrete (NCC) beam. In his work, the experimental data shows that the shear ductility of NCC beams reduces along with the increase of tension reinforcement ratio.

NCC beam's bearing capacity is often improved by increasing the tension reinforcement ratio while its section size and concrete strength cannot be increased. Unfortunately, the high ratio of tension reinforcement leads to the low ductility of NCC beam. The concrete of NCC beam in compression zone is broken before the tension reinforcement reaching its yield. This failure mode of beam is forbidden appearing in engineering.

However, as is shown in Fig.1, the reinforcement is putted in compression zone of RCC beams and the ratio of tension reinforcement is increased. In this way, the reinforcement concrete beam's bearing capacity is improved. But there no data to show whether the shear ductility of RCC beams decreases along with the growth of longitudinal reinforcement ratio. In effort to study the shear ductility of RCC beam the monotonic static load test of 4 RCC beams and 1 NCC beam was carried out.

\section{Experimental Instruction}

\subsection{Specimens}

Experimental beams' cross section size is $150 \mathrm{~mm} \times 300 \mathrm{~mm}$ and are $1500 \mathrm{~mm}$ long. Concrete strength is $40 \mathrm{MPa}$ in the test for concentric compression. The yielding stresses and ultimate stresses of longitudinal reinforcement, which's diameter is $10 \mathrm{~mm}$, are $530 \mathrm{MPa}$ and $660 \mathrm{MPa}$ respectively. The yielding stresses and ultimate stresses of longitudinal reinforcement, which's diameter is $22 \mathrm{~mm}$, are $465 \mathrm{MPa}$ and $632 \mathrm{MPa}$ respectively. The yielding stresses and ultimate stresses of longitudinal reinforcement, which's diameter is $25 \mathrm{~mm}$, are 442MPaand 597 respectively. And the yielding stresses and ultimate stresses of stirrup, which's diameter is $8 \mathrm{~mm}$, are $490 \mathrm{MPa}$ and 614 respectively. Details of specimen are listed in the table 1 and figure 1.

\subsection{Test procedure}

The test was taken at structural laboratory of Fourth Engineering Company of China. Beams were loaded on Counter force test bench using $1000 \mathrm{KN}$ oil jack. The loading equipment is shown in figure 2 . And the loading procedure is shown in figure 3 .

\subsection{Arrangement of measuring points}

In effort to study the working performance of beams, experimental beams' deflection are measured by 5 displacement sensors. They are putted on two beam bearings, loading points and the middle of beam. Strain 
measuring points is arranged in the region where the inclined crack is predicted to expand. Mutual vertical strain gauges on the surface of beams is used to measure the concrete strain. Experimental beam displacement and strain measuring points are shown in figure 4.

Table 1. Specimen parameter

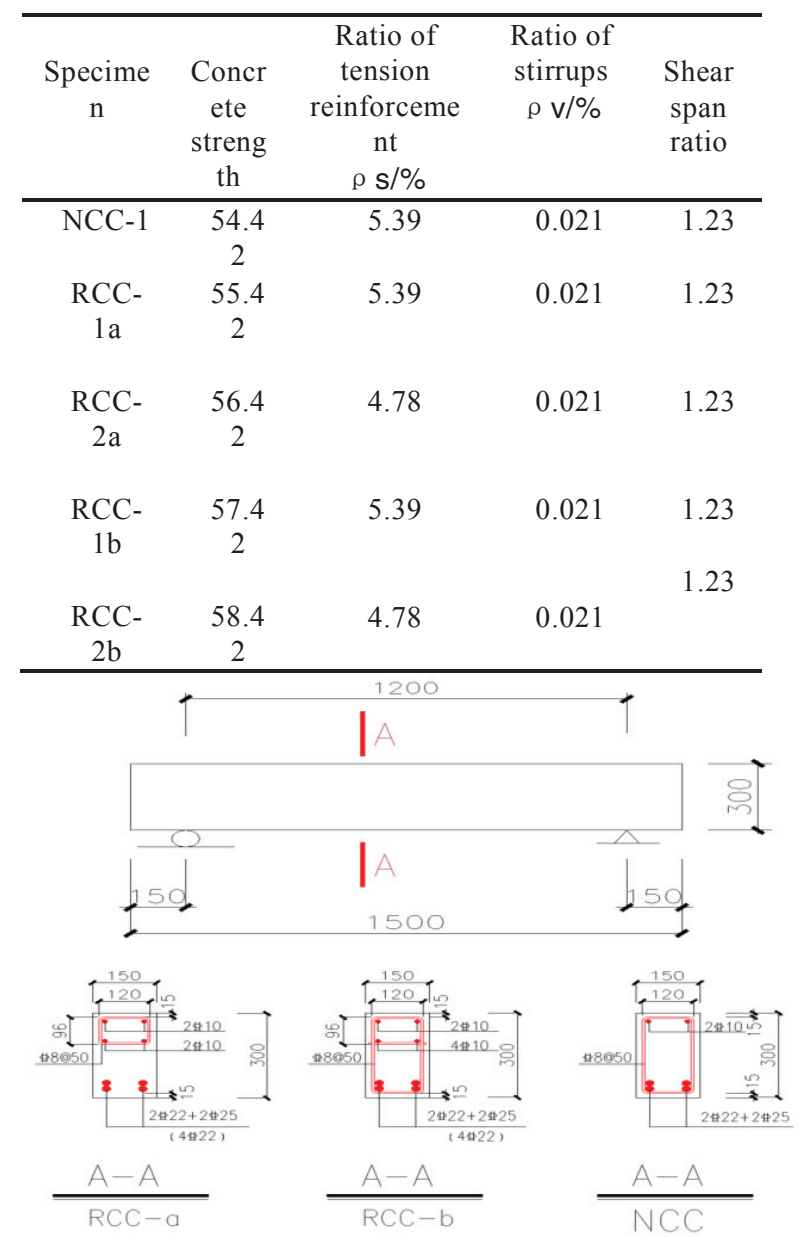

Figure 1. Dimension of specimen and configuration of reinforcement

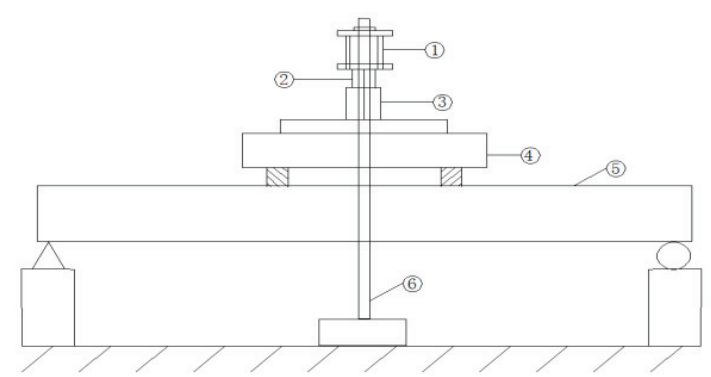

(1) cross girder (2) force sensor (3) hydraulic jack

(4) distributive (5) experimental (6) Force transmitting girder frame

Figure 2. Test setup

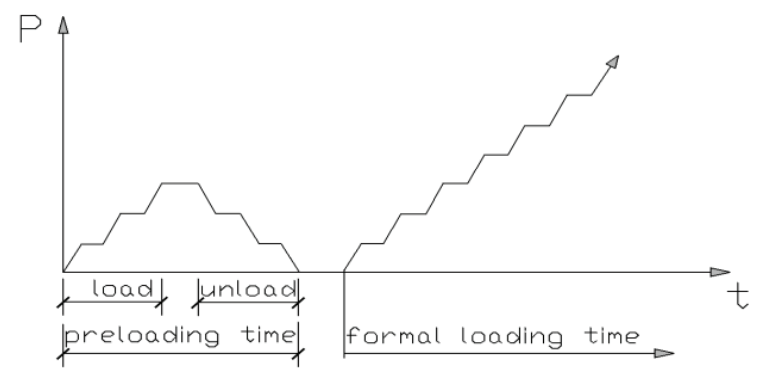

Figure 3. Loading history
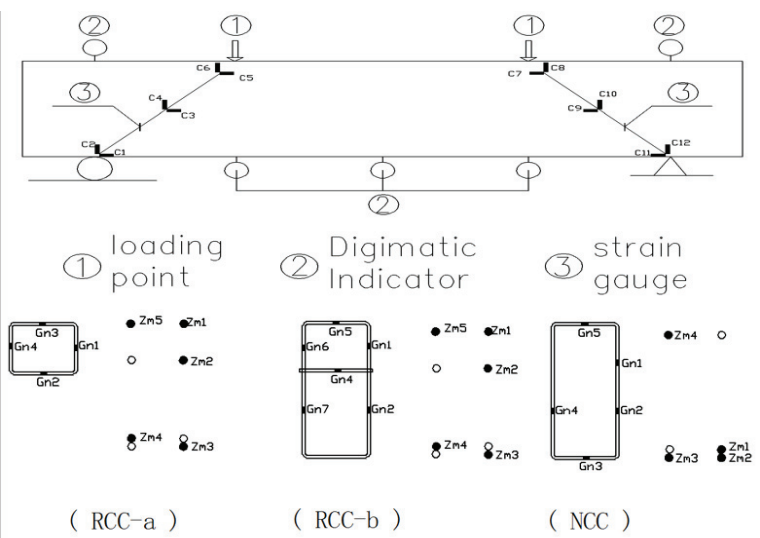

Figure 4. Arrangement of Strain gauges and displacement sensors

\section{Experimental phenomena and analysis of load-deflection curve}

The load-deflection curve of RCC-1a and RCC-1b beams can also be divided into three stages: elastic stage, elastoplastic stage and failure stage. But the loaddeflection curve of RCC beams was different from NCC beam. In the elastic plastic stage, there were three different slope of the curve. The three different slopes of the curve can be seen in the load-deflection of RCC-1b, and RCC-2b beam (Fig.6). The failure stage of NCC beams showed good ductility, as shown in Fig.6.

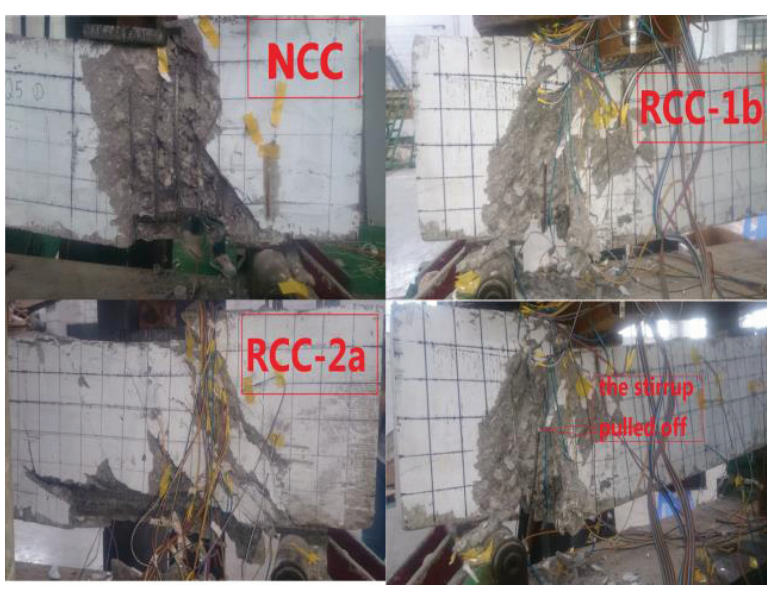

Figure 5. Failure modes for beams 


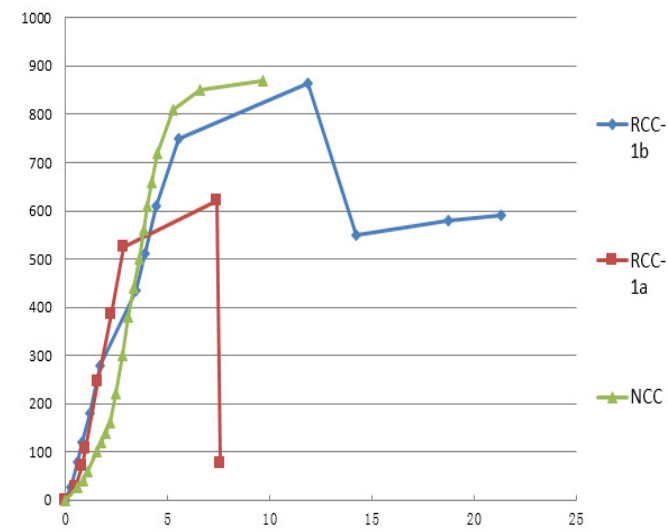

Figure 6. Load-deflection of beams with different stirrup shapes

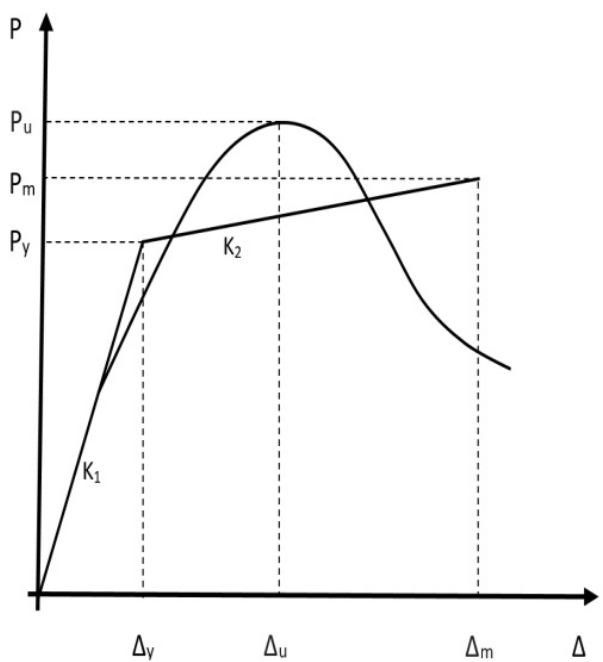

Figure 7. Equivalent method of equivalent shear ductilitycoefficient

\section{Analysis of Shearing Ductility Coefficient}

$\mathrm{T}$ According to the analysis method of the ductility of flexural test beam (Feng 2005), the ductility of shearing test is calculated. Based on the energy equivalent principle, the load-deflection curve is simplified into two linear load-deflection curve. The simplified loaddeflection curve has been showed in figure 7 . In equation form(weijian 2009), it is:

$$
\begin{aligned}
& \mu=\Delta \mathrm{m} / \Delta \mathrm{y} \\
& \left(\mathrm{P}_{\mathrm{y}}^{2} / 2 \mathrm{~K}_{1}\right)+1 / 2\left(\mathrm{P}_{\mathrm{y}}+\mathrm{P}_{\mathrm{m}}\right)\left(\Delta \mathrm{m}-\mathrm{Py} / \mathrm{K}_{1}\right) \\
& \mathrm{P}_{\mathrm{y}}=\mathrm{K}_{1} \Delta_{\mathrm{y}} \\
& \mathrm{P}_{\mathrm{m}}=\mathrm{K}_{1}\left(\Delta \mathrm{m}-\Delta_{\mathrm{y}}\right) \\
& \mathrm{K} 2=0.05 \mathrm{~K}_{1}, \mathrm{Py}=0.75 \mathrm{P}_{\mathrm{u}} \\
& \mathrm{E} \text { - the area of the load deflection and the } \\
& \text { transverse coordinate } \\
& \Delta_{\mathrm{y}} \text {-Simplified yield displacement } \\
& \Delta_{\mathrm{m}} \text {-Simplified limit displacement } \\
& \mathrm{P}_{\mathrm{y}} \text {-Simplified yield load } \\
& \mathrm{P}_{\mathrm{m}} \text {-Simplified ultimate load }
\end{aligned}
$$

$\mathrm{P}_{\mathrm{u}}$-Ultimate load

$\mathrm{K}_{1}$ - Simplified initial stiffness

$\mathrm{K}_{2}$ - Simplified degenerated stiffness

By the Eqns 1, 2 , 3 and 4, the shear ductility coefficient $(\mu)$ can be obtained. Shearing ductility coefficient $(\mu)$ should be standardized to $\mu$, which's loaddeflection curve has significant level line and be listed in Table 2.

Table 2. Equivalent shear ductility coefficient of specimen

\begin{tabular}{cccc}
\hline $\begin{array}{c}\text { Specim } \\
\text { en }\end{array}$ & $\begin{array}{c}\text { Ratio } \\
\text { of } \\
\text { tension } \\
\text { reinfor } \\
\text { cement } \\
\rho \mathrm{s} / \%\end{array}$ & $\begin{array}{c}\text { Equivalent } \\
\text { ductility } \\
\text { coefficient } \\
\mu\end{array}$ & $\begin{array}{c}\text { Calibrat } \\
\text { ion } \\
\text { ductilit } \\
\mathrm{y} \\
\text { coeffici } \\
\text { ent } \\
\mu^{\prime}\end{array}$ \\
\hline $\begin{array}{c}\text { RCC- } \\
1 \mathrm{a}\end{array}$ & 5.4 & 4.75 & 2.63 \\
$\begin{array}{c}\text { RCC- } \\
2 \mathrm{a}\end{array}$ & 4.8 & 7.05 & 3.27 \\
$\begin{array}{c}\text { RCC- } \\
1 \mathrm{~b}\end{array}$ & 5.4 & 7.43 & 3.81 \\
$\begin{array}{c}\text { RCC- } \\
2 \mathrm{~b}\end{array}$ & 4.8 & 4.11 & 1.96 \\
$\mathrm{NCC}$ & 5.4 & 3.66 & 1.83 \\
\hline
\end{tabular}

\section{Effect of tension reinforcement ratio on shear ductility coefficient}

The shear ductility coefficient of the experimental beam changes with the variation of longitudinal reinforcement ratio (Table 2). It can be obtained that the shear ductility coefficient of RCC-a beam decreased with the increase of tension reinforcement ratio. The tension reinforcement ratio increased from $4.8 \%$ to $5.4 \%$, the equivalent ductility coefficient $(\mu)$ decreased from 7.05 to 4.75 . It Has reduced by $32.6 \%$. The calibration ductility coefficient $\left(\mu^{\prime}\right)$ reduced From $3.27 \%$ to $2.63 \%$ and reduced by $19.6 \%$ (Fig. 8 ). The reason is that with the seam shape of the stirrup, the greater the tension reinforcement ratio, the stiffness of the RCC-a beams increases. That leads to the reduction of rotation capacity of the experimental beam. So the RCC-a beam has poor ductility. For the influence of the tension reinforcement ratio on the shear ductility, RCC-a beam has the seam regular with NCC beam.

From Figure 8, the shear ductility coefficient of RCC$\mathrm{b}$ increases with the increase of the tension reinforcement ratio. The tension reinforcement ratio increases from $4.8 \%$ to $5.4 \%$, and the equivalent ductility coefficient $(\mu)$ increased from 4.11 to 7.43 . It increased by $32.6 \%$. Calibration ductility coefficient $\left(\mu^{\prime}\right)$ increased from 1.96 to 3.81 . It increased by $94.4 \%$. And the ductility coefficient increased by nearly one time.

The effect of tension reinforcement ratio on shear ductility coefficient of RCC-b beams is Contrary to the phenomenon and results in the test of normal confined concrete beams (weijian 2009). The reason is that there is a regional confined area in RCC-b beam compared with the normal confined concrete beam. Due to the upper 
concrete of RCC beam strengthened by stirrup and longitudinal reinforcement, the upper concrete of RCC beam belongs to the well confined concrete. The redistribution of internal force is caused along with the emergence of plastic hinge in lower concrete. And the regional confined part has a collaborative work with the tension reinforcement. In that way, the shear ductility of reinforced concrete beam is improved. Therefore, it showed the effect of tension reinforcement ratio on the shear ductility coefficient is different with normal confined concrete beam. However, the RCC-a without stirrups throughout the beam's section, the tension reinforcement is not connected. The regional confined part and the lower longitudinal reinforcement cannot form a loaded body when the weak confined concrete destroyed, which leads to their collaborative work performance has not been fully played. Therefore, the law of influence of tension reinforcement ratio on shear ductility coefficient of RCC-b beam and RCC-a beam is different.

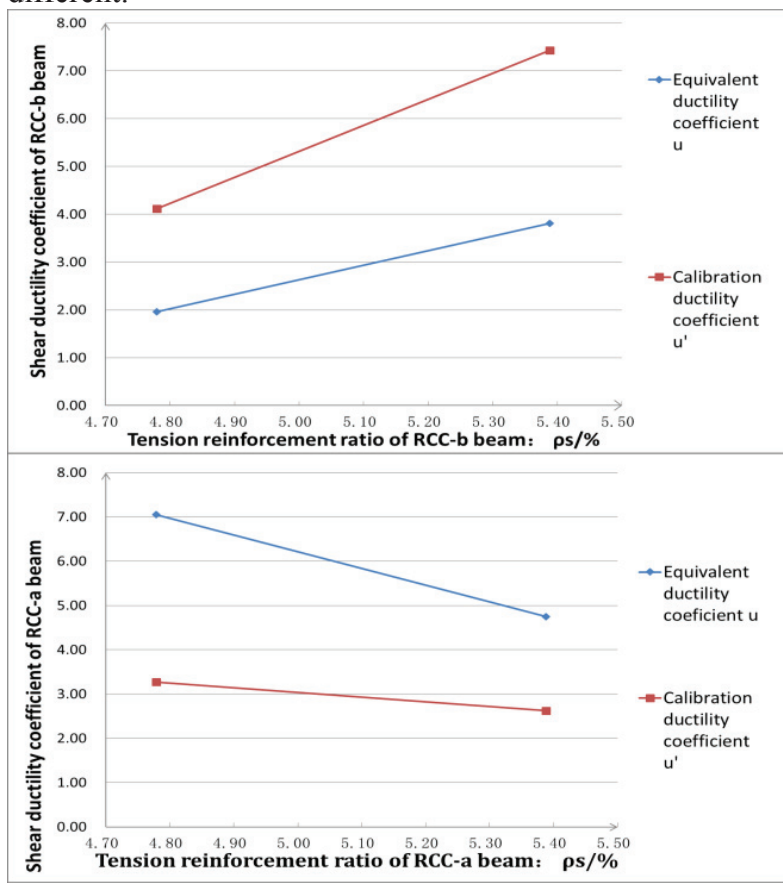

Figure 8. Influence of $\rho s$ on shear ducltility coefficient of RCC beam

\section{Effect of stirrup shapes on shear ductility coefficient}

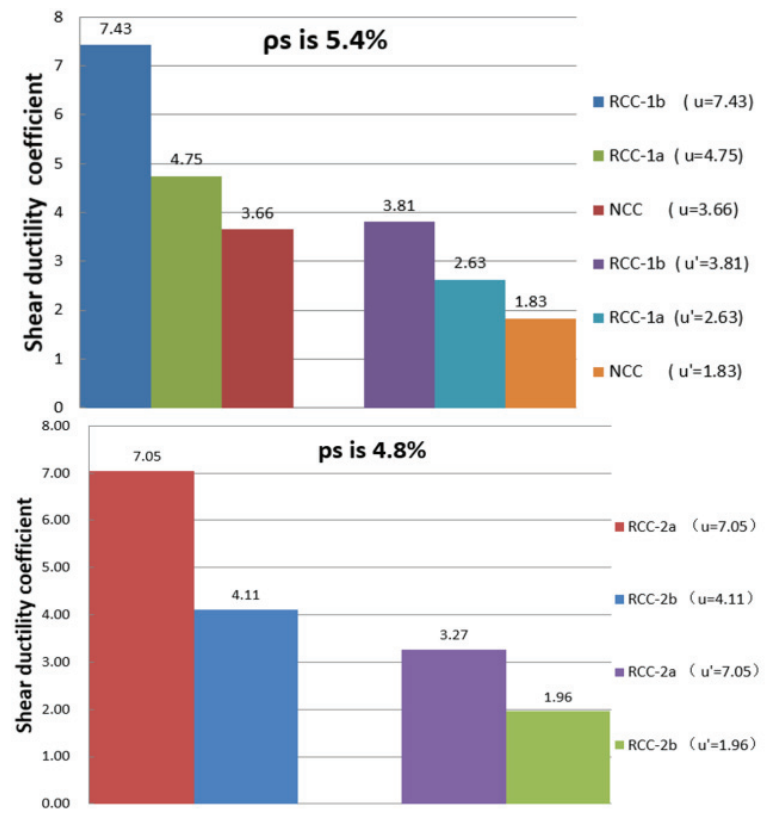

Figure 9. Effect of different stirrups on shear ductility coefficient of specimens

The tension reinforcement ratio in normal confined concrete beam is limited to $2.5 \%$ in the code (2004) because the high tension reinforcement ratio would lead to the low ductility of normal confined concrete beam. Fortunately, the RCC beams with high tension reinforcement ratio has desirable ductility (Fig.9). Therefore, the beam's size can be decreased to save building space with the application of RCC beam.

From figure 9, it can be seen with the tension reinforcement ratio $5.4 \%$, equivalent shear ductility coefficient $\mu$ and calibration of the shear ductility coefficient $\mu^{\prime}$ from NCC, RCC-a to RCC-b beam gradually increases and the increase rate is gradually increased. The shear ductility coefficient of RCC-1a beam is $30 \%$ higher than NCC beam's. What's more, the shear ductility coefficient of RCC-1b beam is $103 \%$ higher than NCC beams. The beam calibration shear ductility coefficient (1.96) does not meet the requirements of seismic ductility. However, the equivalent shear ductility coefficient and the calibrated ductility coefficient of two kinds of regional confined beams meet the seismic demand and have a certain surplus. The shear ductility of RCC-a beam is relative poor when the tension reinforcement ratio is $4.8 \%$. The range of the optimal tension reinforcement ratio of the RCC beam needs to be further studied. The test data shows that deformation and energy dissipation capacity of RCC beam is better than that of the NCC beam. What's more, with the increase of tension reinforcement ratio, the deformation and energy dissipation capacity will be more prominent when compared with the NCC beam. Therefore, it can be inferred that $\mathrm{NCC}$ beam can be made certain contribution in seismic engineering. 


\section{Conclusion}

As a new type of reinforced concrete beam, Regional Confined Concrete beam is different from normal confined concrete beam in the mechanical properties and failure mode. Because of the change of confined mechanism, its mechanical properties can be improved.

(1) The shear ductility coefficient of RCC-a and $\mathrm{RCC}-\mathrm{b}$ is higher than that of NCC beam. It proves that the seismic performance of regional confined concrete beam is more excellent than that of normal confined concrete beam

(2) The shear ductility coefficient of RCC-b beam increases along with the increase of tension reinforcement ratio. And it contradicts with that of $\mathrm{NCC}$ and RCC-a beam.

(3) Because of the experimental beams is not enough, the experimental data is not enough to draw the formula of the ductility and the optimum tension reinforcement ratio, which will be solved in the following research.

(4) With the application of RCC beam, the limit of tension reinforcement ratio in code can be broaden. And the size of reinforcement concrete beam may be decreased to save the costing of architecture safely.

(5) Experimental data proves that the regional confined part improves the reinforced concrete beam's brittle shear failure, the seismic performance and the energy dissipation capacity. The regional confined concrete will has broad application prospect in the construction of antiseismic structure.

\section{Acknowledgements}

This work was carried out at structural laboratory of Fourth Engineering Company of China. And it was supported by Compilation of Code for Design of Regional Confined Concrete Structure of The Guizhou Local Standard (Qian Jian Ke Tong No. [2013]367). Besides, we would like to thank Weixue, Yan Kunhong, Zhou Jianying, Zou Qinwei and Zaolin for their help.

\section{References}

1. Buildings Department of the HKSAR Government. Code of Practice for Structural Use of Concrete 2004, Buildings Department, the HKSAR Government. Hong Kong(2004)

2. Cao, X. M., Huang, X. W., Mo, Z. G., \& Tian, H. Y.. "Introduction of regional confined concrete", Advanced Materials Research, 671-674, 697703(2013)

3. Feng, P., Lie-Ping, Y. E., \& Huang, Y. L. "Deformability and new performance indices of flexural members", Engineering Mechanics, 22(6), 28-36 (2005)

4. Agency, F. E. M.. Nehrp guidelines for the seismic rehabilitation of buildings (fema publication 273), Wbdg Org (1997)

5. Park, R., Paulay, T. Reinforced Concrete Structures, John Wiley \&Sons Inc, p203-208 (1975).

6. Weijian, Y. I, \& Yanmei, L. "Experimental study on shear behavior of high-strength concrete beams with high-strength stirrups", Journal of Building Structures, 30(4), 94-101 (2009).

7. Xie, Y., Ahmad, S. H., Yu, T., Hino, S., \& W. Chung. "Shear ductility of reinforced concrete beams of normal and high-strength concrete" Aci Structural Journal, 91(2), 140-149 (1994) 